\title{
Prevalence of MEFV gene mutations in apparently healthy Slovenian and Macedonian population
}

\author{
M Debeljak ${ }^{1 *}$, N Abazi ${ }^{3}$, N Toplak ${ }^{2}$, K Stavrić ${ }^{3}$, M Kolnik ${ }^{2}$, D Kuzmanovska ${ }^{3}$, T Avčin ${ }^{2}$ \\ From 18th Pediatric Rheumatology European Society (PReS) Congress \\ Bruges, Belgium. 14-18 September 2011
}

\section{Background}

Familial Mediterranean Fever (FMF) is an autosomalrecessive disorder characterized by recurrent attacks of fever and serositis. It is common in eastern Mediterranean population. There are only few FMF patients in Slovenia and Macedonia and the mutation carrier rate is not known. So far, over 80 disease associated mutations have been identified in $M E F V$ gene; the most common are M694V, V726A, M680I, E148Q and M694I.The distribution pattern of $M E F V$ mutation along the Mediterranean Sea is not uniform; eastern populations have the highest number of carriers (20-39\%), whereas the number of carriers in western Mediterranean populations is considerably lower.

\section{Aim}

The aim of this study was to determine the carrier rate in apparently healthy Macedonian and Slovenian populations.

\section{Methods}

We screened 100 subjects from both populations. Exon 10 was PCR amplified and screening was performed with dHPLC. All amplicons with detected nucleotide changes were subsequently sequenced with ABI Prism 310 Genetic analyzer. Amplicons of exon 2 were directly sequenced.

\section{Results}

Heterozygous mutations were found in $7 \%$ of apparently healthy Slovenians and in $16 \%$ of apparently healthy Macedonians. Mutations found in Slovenian population were as follows: V726A (4), K695R (2) and E148Q (1).

${ }^{1}$ Center for Medical Genetics, University Children's Hospital, University Medical Center, Ljubljana, Slovenia

Full list of author information is available at the end of the article
Mutations found in Macedonian population were as follows: E148Q (8), K695R (7) and M694V (1).

\section{Conclusion}

We found higher than expected carrier rate in both populations, $7 \%$ and $16 \%$, respectively. It is interesting to note that almost half of detected carriers in Macedonian and one third in Slovenian population have a K695R mutation.

\section{Author details}

${ }^{1}$ Center for Medical Genetics, University Children's Hospital, University Medical Center, Ljubljana, Slovenia. ${ }^{2}$ Department of Allergology, Rheumatology and Clinical Immunology, University Children's Hospital, University Medical Center, Ljubljana, Slovenia. ${ }^{3}$ University Children Hospital, Medical Faculty, Ss. Cyril and Methodius University, Skopje, Republic of Macedonia.

Published: 14 September 2011

doi:10.1186/1546-0096-9-S1-P301

Cite this article as: Debeljak et al: Prevalence of MEFV gene mutations in apparently healthy Slovenian and Macedonian population. Pediatric Rheumatology 2011 9(Suppl 1):P301.

Submit your next manuscript to BioMed Central and take full advantage of:

- Convenient online submission

- Thorough peer review

- No space constraints or color figure charges

- Immediate publication on acceptance

- Inclusion in PubMed, CAS, Scopus and Google Scholar

- Research which is freely available for redistribution 